\title{
Relationship between Indoor High Frequency Size Distribution of Ultrafine Particles and Their Metrics in a University Site
}

\author{
Fabio Boccuni $* \mathbb{*}$, Riccardo Ferrante, Francesca Tombolini, Sergio Iavicoli ${ }^{\dagger}$ and Armando Pelliccioni ${ }^{\dagger}$
}

Citation: Boccuni, F.; Ferrante, R.; Tombolini, F.; Iavicoli, S.; Pelliccioni, A. Relationship between Indoor High Frequency Size Distribution of Ultrafine Particles and Their Metrics in a University Site. Sustainability 2021, 13, 5504. https://doi.org/ $10.3390 /$ su13105504

Academic Editor: Paolo Monti

Received: 19 April 2021

Accepted: 12 May 2021

Published: 14 May 2021

Publisher's Note: MDPI stays neutral with regard to jurisdictional claims in published maps and institutional affiliations.

Copyright: (c) 2021 by the authors. Licensee MDPI, Basel, Switzerland. This article is an open access article distributed under the terms and conditions of the Creative Commons Attribution (CC BY) license (https:/ / creativecommons.org/licenses/by/ $4.0 /)$.
Italian Workers' Compensation Authority (INAIL), Department of Occupational and Environmental Medicine, Epidemiology and Hygiene, I-00078 Rome, Italy; ri.ferrante@inail.it (R.F.); f.tombolini@inail.it (F.T.); s.iavicoli@inail.it (S.I.); a.pelliccioni@inail.it (A.P.)

* Correspondence: f.boccuni@inail.it; Tel.: +39-(0)-6-94181559

+ These authors contributed equally to this work.

Abstract: Exposure to ultrafine particles (UFPs size $<100 \mathrm{~nm}$ ) in life and work environments can contribute to adverse health effects also in terms of health burden of related diseases over time. The choice of parameters which better characterize UFPs is challenging, due to their physical-chemical properties and their variable size. It is also strictly related to the availability of different instrumental techniques. In the present study we focus on real time high frequency $(1 \mathrm{~Hz})$ UFPs particle size distribution (PSD) and their relationship with total particle number concentration (TPNC) and mean particle diameter $\left(D_{a v g}\right)$ as a contribution characterizing by size the human exposure to UFPs in an indoor site of the University of Rome "Sapienza" (Italy). Further considerations about UFPs contribution to nucleation mode (NM) and accumulation mode (AM) have been highlighted, also in order to investigate the contribution of polycyclic aromatic hydrocarbons (PAHs) surface-adsorbed on indoor air particles (pPAHs). High indoor TPNC values were registered during the rush hours (early morning and mid/late afternoon) according to the outdoor influences originated from anthropogenic activities. AM mainly contribute to the indoor TPNC during working days showing high correlation with pPAHs. These findings may provide useful indications in terms of occupational exposure to UFPs since there are many evidences that indoor exposures to such pollutants may be associated with adverse health effects also in working environments.

Keywords: indoor air quality; particulate matter; ultrafine particles; size distribution; particle number concentration

\section{Introduction}

Ambient particulate matter (PM) is considered one of the leading environmental health risk factors, associated with several health impacts worldwide [1]. Among the important and variable parameters of PM that may be linked with health consequences of exposures is the particle size [2]. Ambient aerosols generally include particles with aerodynamic diameter between $0.01 \mu \mathrm{m}$ and $100 \mu \mathrm{m}$. Particles between $2.5 \mu \mathrm{m}$ and $10 \mu \mathrm{m}$ are defined as coarse particles, and particles between $2.5 \mu \mathrm{m}$ and $0.1 \mu \mathrm{m}$, as fine particles, whereas particles with diameter less than $0.1 \mu \mathrm{m}$ are defined as ultrafine particles (UFPs) or nanoparticles [3,4].

Many studies have shown that UFPs can contribute to adverse health effects in life and work environments [5-11], measurable also over time in terms of health burden of related diseases [12]. UFPs are very small compared with the cellular structures and so this may be important in the consequences they may cause to the lung [13]. A particular concern is their ability to reach the most distal lung regions (alveoli) and circumvent primary airway defenses. When inhaled, UFPs can pass through the respiratory tract with high efficiency down to the alveoli due to their small size. A fraction of UFPs penetrates the alveolar-capillary barrier and can thus be distributed throughout the body via the circulatory system [14]. Because of this property of UFPs, extra-pulmonary diseases related 
to PM exposure may be particularly attributable to UFPs [15]. Furthermore, UFPs are considered more harmful than larger PM due to their higher specific surface area (total exposed surface area per unit of mass). Large surface area and high surface reactivity enable UFPs to adsorb, for a given mass of PM, greater quantities of hazardous metals, and organic compounds that can generate oxidative stress [5]. In a recent study, Costabile et al. (2020) [16] concluded that pro-inflammatory and oxidative responses occurred when the aerosol was dominated by a UFP type apportioned to fossil fuel combustion with number size distribution dominated by particles smaller than $20 \mathrm{~nm}$.

\subsection{UFPs Outdoor Sources}

UFPs in indoor environments are influenced by both indoor and outdoor sources [17]. In this context, an overview of main outdoor source contributions is needed. With respect to their formation mechanism, UFPs are usually considered as belonging to two types. The smallest is the nucleation mode (NM, particle size $<30 \mathrm{~nm}$ ), which includes UFPs newly formed through source condensation processes or atmospheric chemical reactions: usually formed by volatile precursors as exhaust dilutes and cools, they have short atmospheric life (minutes). Otherwise, particles with aerodynamic diameter greater than $30 \mathrm{~nm}$ tend to have longer atmospheric lifetimes. The higher number and larger surface area for a given mass concentration favor the occurrence of condensation and coagulation processes. In this way these particles grow into the accumulation mode (AM, typically in the size range $30 \mathrm{~nm}-1 \mu \mathrm{m}$, but may be larger under high relative humidity conditions) which contains primary and secondary particles with longer atmospheric life (days) [15,18-22].

UFPs particles may be also classified by their source contribution in natural (e.g., marine aerosol, volcanic eruptions) [23,24] and anthropogenic, typically generated through combustion of biomass (e.g., tobacco smoking, wood burning, incense burning) or fossil fuels (e.g., coal, natural gas, diesel) [25]. In the last years other sources of anthropogenic UFPs - that may present also correlations with indoor environments-were introduced, referred as nanomaterials either deliberately produced (i.e., engineered nanomaterials) or not voluntarily derived by production processes (defined as incidental) [26-28].

Motor vehicles, especially those driven by diesel engines, have been indicated as a major source of ambient UFPs emission $[15,29]$. UFPs can be formed from the condensation in the gas phase of semi-volatile organic compounds (SVOCs) that bypass the filtration technology [30]. On-road submicron particle size distribution typically contains an AM with estimated number mean diameter of $100 \mathrm{~nm}$, consisting of carbonaceous agglomerates, e.g., elemental carbon and organic carbon that includes polycyclic aromatic hydrocarbons (PAHs). Vehicular traffic is an important source of particle-bound PAHs (pPAHs) [31]. Diesel and spark ignition vehicles also contribute to the occurrence of NM and his formation is extremely dependent on the dilution conditions of the engine exhaust [32].

UFPs generated from combustion of gasoline and diesel differ in chemical composition from those generated by solid fuel combustion. Coal combustions can be considered as one of the main contribution to the anthropogenic budget of NM, in both rural and urban areas $[33,34]$. The exact size depends on the distance from the source and the available time for coagulation and growth, although they are well below the range in which direct effects of solar radiation through scattering and absorption are important $(>300 \mathrm{~nm})$ [35-37].

Other source of UFPs is represented by biomass burning, natural or accidental (e.g., wildfire burning) and anthropogenic (e.g., biomass fuels such as peat, trees, leaves, and grass). The smoldering phase of biomass burning is associated with long-term output of UFPs and particles in AM, showing a bimodal distribution, with the smallest mode at $\sim 10 \mathrm{~nm}$ and the dominant mode of the particle-size distribution was in the range of $29-52 \mathrm{~nm}[38,39]$.

\subsection{UFPs Indoor Sources}

If abundant literature is available concerning outdoor sources, indoor sources characterization is far less defined. Buildings provide moderate, yet incomplete protection against 
UFPs of outdoor origin. With regard to infiltration of ambient particles from outside, it is quantified by the infiltration factor, which, in turn, is a function of several parameters, such as building construction characteristics (e.g., cracks, internal sources), air exchange mechanisms, outdoor meteorological conditions and indoor air circulation [40,41].

Indoor UFPs derives also from the emissions of indoor sources [42-44] which include cooking, domestic heating, smoking [45], use of electric appliances and chemical products, abrasion of textile materials and presence of individuals as well as UFPs emitted from building and furnishings materials [41,46].

In working environments aforementioned sources are missing and those ascribable to the presence of people become of particular importance, such as particle resuspension, clothes abrasion and bioaerosol release (i.e., skin fragments) [47-49]. Consumer products such as cleaning agents, air fresheners and personal care products contain terpene species, such as limonene, $\alpha$-pinene or $\alpha$-terpinolene [50]. Emissions of such species and subsequent chemical reactions indoors can allow the formation of numerous multifunctional and sometimes harmful secondary pollutants [51] such as VOCs which have low enough vapour pressures such that they partition to the particle phase to form secondary organic aerosols (SOA) [52,53].

Laser printers are another of the major contributors of UFPs in office environments [54]. UFPs formation may happen through nucleation and condensation of VOCs or SVOCs released by the fuser, which comprises siloxanes and fluorinated compounds, or emitted from the chassis, which holds flame retardants, lubricants, and plasticizers, in a typical bimodal PSD, with a smaller mode $<10 \mathrm{~nm}$ and a broader mode extending from $\sim 40 \mathrm{~nm}$ up to $100 \mathrm{~nm}$ [55].

\subsection{UFPs Metrics}

In this framework research questions are still open about UFPs metrics and indicators of interest that might be used to characterize potential emissions, air quality, exposure and health effects $[15,20]$. Exposure to UFPs is a big challenge, due to their physical-chemical properties and their variable size $[4,56]$, which may influence the choice and availability of instrumental techniques. Major measurement parameters include: total particle number concentration (TPNC), particle size distribution (PSD, i.e., particle number concentration per each size bin), mass concentration and lung deposited surface area (LDSA). Usually, only some of these parameters are measured, and in addition not simultaneously [57]. A common measure of UFPs prevalence is the TPNC: UFPs dominate TPNC and have negligible particle mass concentrations. Further findings support the concept that LDSA is the dose measure that predicts pulmonary response, rather than mass $[5,13]$.

In the present paper we focus on UFPs PSD dynamics and their relationship with TPNC and mean particle diameter $\left(D_{\text {avg }}\right)$ as a contribution to characterize by size the human exposure to UFPs in a University classroom. In this view, we analyzed real time high frequency $(1 \mathrm{~Hz})$ data from a measurements campaign conducted in the winter period in a computer room (CR) at the University site of Rome "Sapienza" (Italy), to describe airborne UFPs by working and non-working days and by daily time slots. Different contributions of NM and AM are studied in detail to investigate the formation mechanisms of indoor UFPs. Further considerations about pPAHs concentration and PSD were proposed, in order to highlight the ultrafine fraction of such pollutants in indoor air.

The present study is a part of the INAIL project "VIEPI" (Integrated Evaluation of Indoor Particulate Exposure, activity no. 3 "Indoor and outdoor particle number concentration") [41] in which extensive experimental activities for chemical and biological characterization of PM, as well as investigation of infiltration/exfiltration mechanisms, were conducted with the final aim to increase knowledge on the relationships between meteorological parameters, indoor airflow, and PM concentration. 


\section{Materials and Methods}

\subsection{Measurement Strategy}

High frequency $(1 \mathrm{~Hz})$ real time measurements were conducted in the CR of the Physics Department of Rome University "Sapienza" ("Enrico Fermi" building) from Saturday 23 November 2017 to Thursday 27 November 2017. The CR is located at the second floor, it has a volume of $450 \mathrm{~m}^{3}$ and it includes about 50 workstations (each equipped with personal computer case, screen, keyboard and mouse) for a maximum capacity of 80 persons. Natural ventilation of the room is provided by the windows placed on the East side, while hot-water radiators are operating during the sampling period as heating appliances integrated by air conditioning devices, manually managed by the occupants (Figure 1). Laser printers are located in the internal hallway placed on the West side of the CR. Outside the CR faces East on the courtyard that, in south direction, is $50 \mathrm{~m}$ far away from a road characterized by high traffic volumes and vehicular emission. During the working days a succession of teaching activities, exercises and exams took place in the $\mathrm{CR}$ without interruption from 8 a.m. to 6 p.m. We estimated that the $\mathrm{CR}$ was occupied by about 42 students on average, with a turnover of students between different classes. Windows were generally opened for a few minutes at the end of each lesson [41].
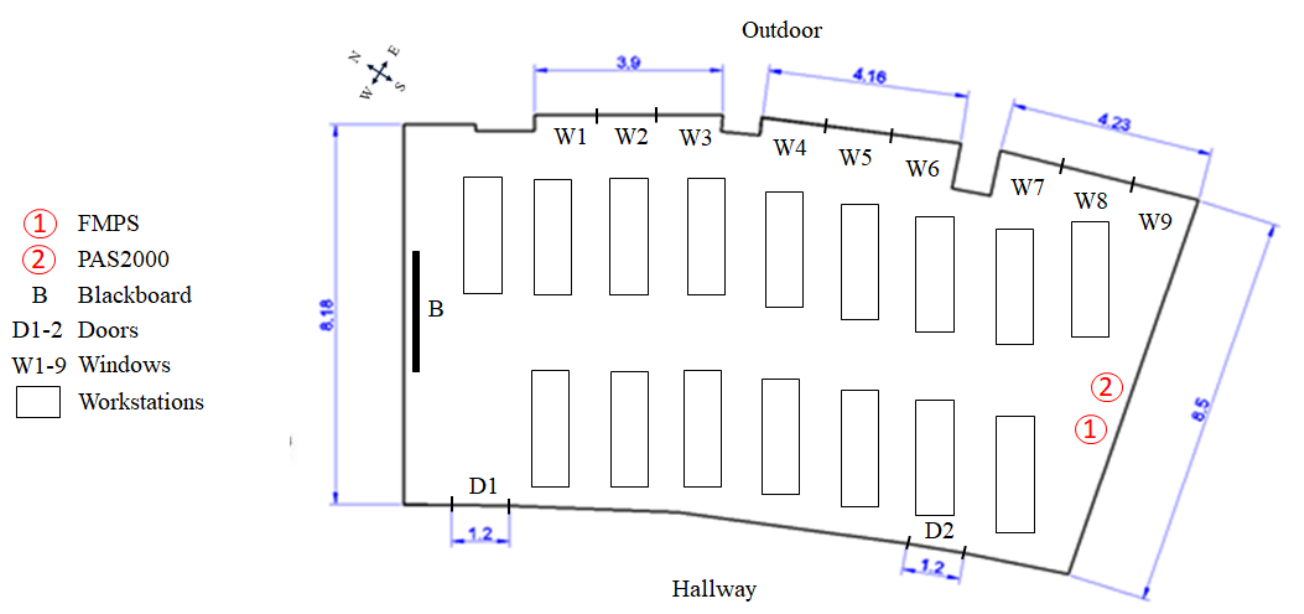

Figure 1. Computer room (CR) layout modified from Pini et al. [58].

In the present study data relating to non-working days (Saturday and Sunday) were grouped and indicated with P1, those relating to Monday are indicated with P2 and Tuesday, Wednesday and Thursday with P3. We reasonably assume that a transition of sources in indoor environments may happen on Monday, therefore the related data were processed separately. Six 4-h time slots were considered: T1 (0 a.m. -4 a.m.), T2 (4 a.m.8 a.m.), T3 (8 a.m.-12 p.m.), T4 (12 p.m.-4 p.m.), T5 (4 p.m.-8 p.m.) and T6 (8 p.m.-0 a.m.). $\mathrm{T} 1$ and $\mathrm{T} 6$ represent the night-time slot, T2 the night-day transition, T3 the morning slot, $\mathrm{T} 4$ the afternoon slot and T5 the day-night transition. T3, T4 and the first half of T5 are the time slots including working and learning activities inside the CR.

\subsection{Equipment}

Two instruments are used in parallel in this study:

- $\quad$ Fast mobility particle sizer (FMPS mod. 3091, TSI Inc., Shoreview, MN, USA)) that is based on the ionic mobility principle and it is used to obtain the normalized PSD $\mathrm{dN} / \mathrm{d} \log \mathrm{Dp}\left(\mathrm{part} / \mathrm{cm}^{3}\right)$ in the size range $5.6-560 \mathrm{~nm}$ divided into 32 different channels and the TPNC, with $1 \mathrm{~s}$ time resolution (total flow $10 \mathrm{~L} / \mathrm{min}$ ).

- PAS 2000 (EcoChemAnalytics, League City, TX, USA) to measure pPAHs surfaceadsorbed on carbon aerosol with aerodynamic diameter less than $1 \mu \mathrm{m}$, with a response time of $10 \mathrm{~s}$ in a measuring interval from 0 to $1000 \mathrm{ng} / \mathrm{m}^{3}$ and a lower detection limit of $3 \mathrm{ng} / \mathrm{m}^{3}$ (total flow $1 \mathrm{~L} / \mathrm{min}$ ). 
Further specifications about such instruments and their affordability are reported elsewhere [59-61]. Both PAS 2000 and FMPS measurements occurred simultaneously at the same location inside the CR. The instrument probes were placed at about $1.5 \mathrm{~m}$ from the $\mathrm{CR}$ ground, far from the windows/doors, the heating sources, the workstations and blackboard (Figure 1).

\subsection{Statistical Modelling Approach}

TPNC (part $/ \mathrm{cm}^{3}$ ) is referred in the following, as the sum of particle number concentration (PNC) of all particles having size between $5.6 \mathrm{~nm}$ and $560 \mathrm{~nm}$, while normalized PSD dN/dlogDp is the particle concentration of each of the 32 channels in the instrumental range $5.6-560 \mathrm{~nm}$, generally used to compare data from instruments with different resolutions [62].

Based on PNC, the averaged diameter $\left(D_{\text {avg }}\right)$ was calculated at each time $(t)$ according to:

$$
D_{\text {avg }}(t)=\frac{\sum_{j} N_{j}(t) \cdot d_{j}}{\sum_{j} N_{j}(t)}
$$

where $N_{j}$ is the PNC related to the $j_{\text {th }}$ diameter $d_{j}$, with $j$ ranging from $5.6 \mathrm{~nm}$ to $560 \mathrm{~nm}$ (into the 32 different channels of FMPS).

Principal component analysis (PCA) [63] was performed as qualitative tool on the original dataset composed of 288 rows (averaged data every half hour for six days) and 4 columns (TPNC, NM, AM and pPAHs), in order to explore independent factors (principal components) that will illustrate the variation of dependent variables such as pPAHs and TPNC during the six time slots (T1-T6) in the non-working and working days.

The relationship between high frequency distribution and metrics has been studied according to the NM and AM mode. Data analysis of the observed distributions based on conventional statistical approach and on the evaluation of high frequency distribution were performed using OriginPro ${ }^{\circledR} 2020$ (OriginLab Corp., Northampton, MA, USA).

\section{Results}

\subsection{TPNC and $D_{\text {avg }}$ Time Series}

Time series of TPNC and $D_{\text {avg }}$ (mean values every $30 \mathrm{~min}$ ) are shown day by day, in Figure 2. The daily mean TPNC values for Saturday and Sunday are $8485 \mathrm{part} / \mathrm{cm}^{3}\left(D_{\text {avg }}\right.$ $55 \mathrm{~nm})$ and 8977 part $/ \mathrm{cm}^{3}\left(D_{\text {avg }} 60 \mathrm{~nm}\right)$ respectively. They represent the lowest TPNC mean values if compared to the other days: Monday $14,160 \mathrm{part} / \mathrm{cm}^{3}\left(D_{\text {avg }} 73 \mathrm{~nm}\right)$, Tuesday $15,979 \mathrm{part} / \mathrm{cm}^{3}\left(D_{\text {avg }} 71 \mathrm{~nm}\right)$, Wednesday 13,084 part $/ \mathrm{cm}^{3}\left(D_{\text {avg }} 73 \mathrm{~nm}\right)$ and Thursday $15,355 \mathrm{part} / \mathrm{cm}^{3}\left(D_{\text {avg }} 67 \mathrm{~nm}\right)$.

TPNC time series show everyday a similar trend that is particularly evident from Monday to Thursday: TPNC reach the highest values about at midnight, then they decrease to a relative minimum between 6 a.m. and 8 a.m., going up to a relative maximum between 8 a.m. and 12 p.m. and reaching another minimum value between 12 p.m. and 4 p.m. Then, the TPNC trend is increasing until it reaches the daily maximum $\left(>20,000\right.$ part $\left./ \mathrm{cm}^{3}\right)$ at about midnight. Thursday differs slightly from this trend showing the daily maximum value between 8 a.m. and 12 p.m.

A similar trend is also appreciable during Saturday and Sunday even if the TPNC values are lower than the working days. The observed distribution during the whole campaign is shown in the contour plot of particle diameter and normalized PSD versus time (Figure $2 b$ ). In the red area it shows that, in the working days at about midnight and in the early morning hours, the PNC highest values range from 2000 part $/ \mathrm{cm}^{3}$ to $2600 \mathrm{part} / \mathrm{cm}^{3}$ for the particle sizes in the interval $60-115 \mathrm{~nm}$.

High TPNC values in CR are according to the outdoor during the rush hours (early morning and mid/late afternoon) $[41,64,65]$. In the winter period, outdoor TPNC peaks at rush hours (in the morning and in the evening) can be considered as the result of the motor vehicle emissions combined with the mixing layer height and low ambient temperature, which favors nucleation mechanisms, at least for particles with dimensions up to some 
tenths of a nanometer [66]. Furthermore the TPNC outdoor reflects the daily profiles of population mobility indicators already proposed by Gariazzo and Pelliccioni [67] for the city of Rome in their study on urban population mobility using mobile phone traffic data.

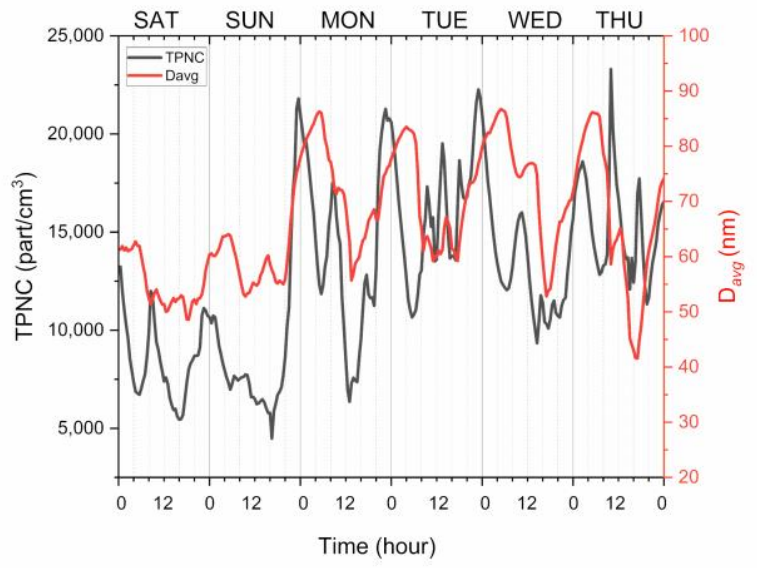

(a)

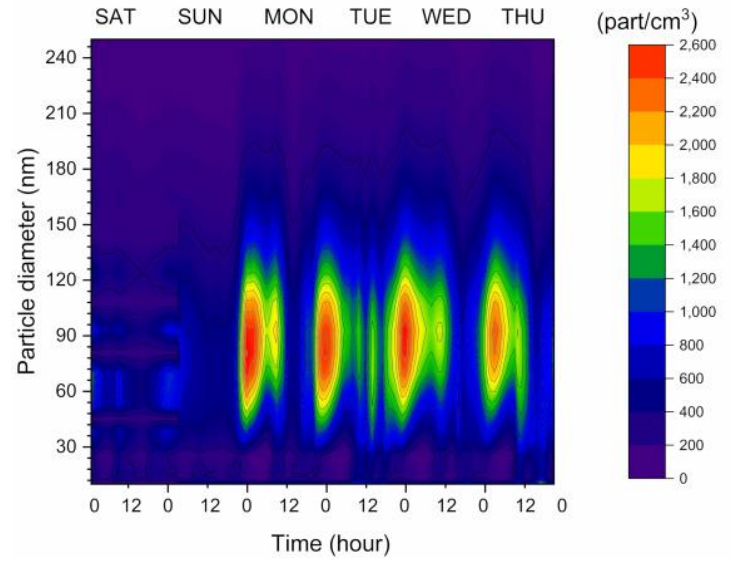

(b)

Figure 2. (a) Indoor time series of total particle number concentration (TPNC, black curve) and average diameter $\left(D_{a v g}\right.$, red curve); (b) contour plot of indoor particle diameter and particle size distribution (PSD, part $/ \mathrm{cm}^{3}$ ) versus time.

\subsection{Relationship between NM and AM and Their Contributions to UFPS}

In Figure 3 PSD during working (P2, P3) and non-working days (P1) for the six 4-h time slots (T1-T6) are shown. The observed distributions are essentially composed by three modes. Since the peak of lower Aitken mode [19,21] at about $20 \mathrm{~nm}$ is negligible compared to the first one (centered at about $10 \mathrm{~nm}$ ), two mono-modal distributions were used: the first distribution concerns particle diameters less than $30 \mathrm{~nm}$ and the second one refers to particle diameters greater than $30 \mathrm{~nm}$, respectively referred to $\mathrm{NM}$ and $\mathrm{AM}$ as classified in literature $[15,18,19]$.

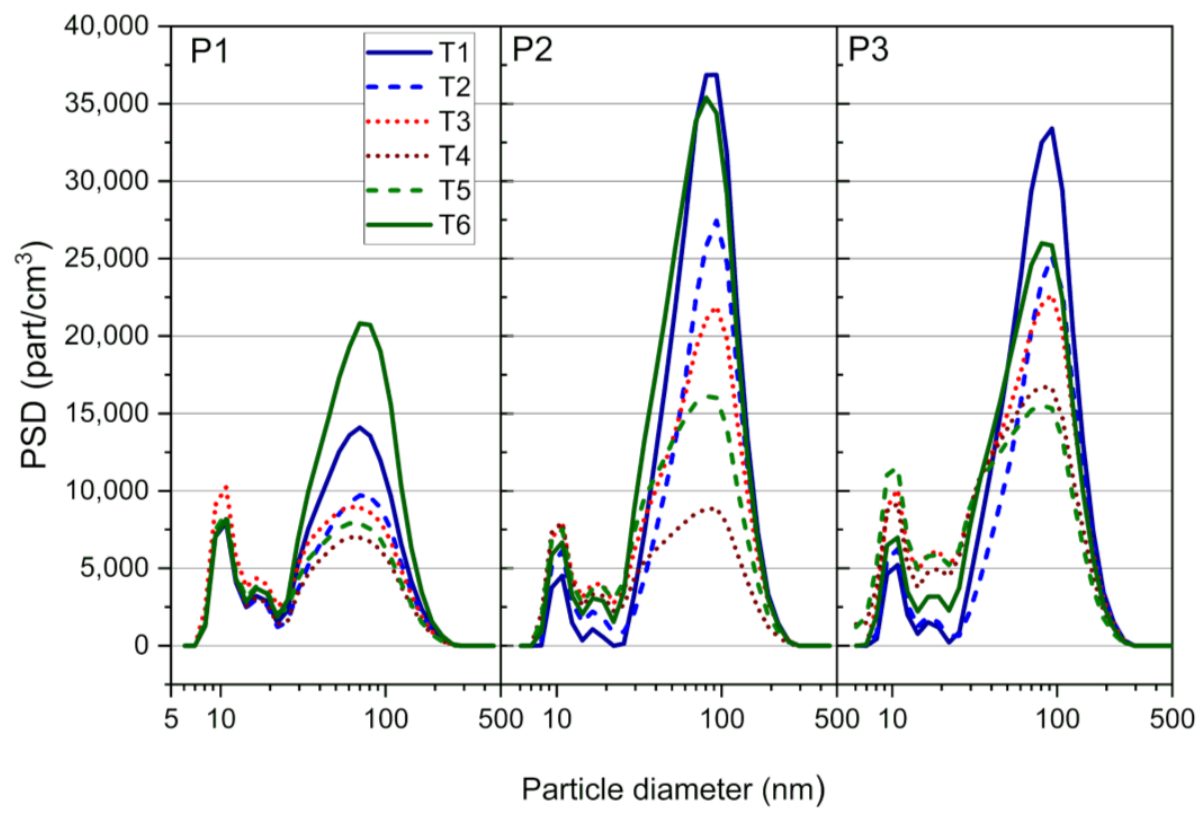

Figure 3. Particle size distribution (PSD) during P1, P2 and P3 for the six time slots (T1-T6). 
In Table 1 are reported the PSD values for P1, P2 and P3 during the different time slots (T1-T6), for NM and AM distributions.

Table 1. Particle size distribution (PSD) values, for P1, P2 and P3 in the six time slots (T1-T6) for nucleation mode (NM) and accumulation mode (AM): mean, standard deviation (Std. Dev.) and coefficient of variation $(\mathrm{CV})$.

\begin{tabular}{ccccccc}
\hline & \multicolumn{3}{c}{$\mathbf{N M}\left(\mathbf{P a r t} / \mathbf{C m}^{\mathbf{3}}\right)$} & \multicolumn{3}{c}{ AM $\left(\mathbf{P a r t} / \mathbf{C m}^{\mathbf{3}}\right)$} \\
\cline { 2 - 7 } & $\mathbf{P 1}$ & $\mathbf{P 2}$ & $\mathbf{P 3}$ & $\mathbf{P 1}$ & $\mathbf{P 2}$ & P3 \\
\hline T1 & 3464 & 1263 & 1745 & 7867 & 18,122 & 16,516 \\
T2 & 3246 & 1971 & 1945 & 5654 & 12,865 & 11,952 \\
T3 & 4578 & 3657 & 5410 & 5571 & 11,775 & 12,748 \\
T4 & 3260 & 3318 & 5189 & 4272 & 5492 & 10,468 \\
T5 & 3787 & 3719 & 6224 & 4779 & 9809 & 9642 \\
T6 & 3864 & 3203 & 3432 & 11,488 & 18,870 & 14,279 \\
\hline Mean & 3700 & 2855 & 3991 & 6605 & 12,822 & 12,601 \\
Std. Dev. & 502 & 1004 & 1896 & 2690 & 5071 & 2526 \\
\hline CV & 0.14 & 0.35 & 0.47 & 0.41 & 0.39 & 0.20 \\
\hline
\end{tabular}

The PSD mean values for NM distribution are 3700, 2855 and 3991 part $/ \mathrm{cm}^{3}$ for P1, P2 and P3 respectively. The standard deviation lowest value occurs for P1 (502 part $\left./ \mathrm{cm}^{3}\right)$ indicating that $\mathrm{P} 2$ and $\mathrm{P} 3$ are more widespread than P1. It is worth noting that the coefficients of variation (CV) are respectively $0.14,0.35$ and 0.47 for P1, P2 and P3. These findings highlight that during the weekend the NM distributions are about the same and not dependent by the time slot, while during the working days higher variability occurred. For AM distributions, the PSD values are always greater than the NM mode. On Monday (P2) some specific features have to be mentioned, related to NM and AM distributions by time slot, highlighting a possible transition of sources in the indoor environment between non-working days (P1) and the other working days (P3).

To take into account the specific contribution (in percentage) of each particle size, PSD values were calculated (PSD\%) respect to the daily total concentration [68-70].

Starting from Figure 4, PSD\% values for NM and AM distributions were reported in Table 2, where the sum of AM and NM values respectively for P1, P2 and P3, is equal to $100 \%$ (corresponding to the bi-modal distribution subtended area).

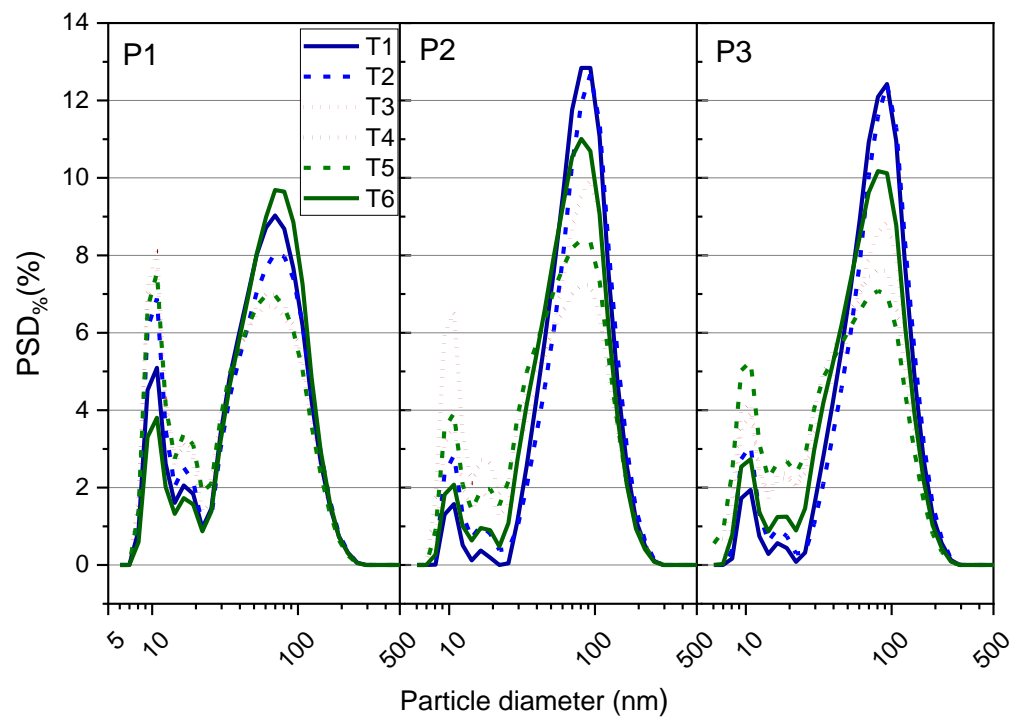

Figure 4. Particle size distribution respect to the daily total concentration (PSD\%) during P1, P2 and P3 for the six time slots (T1-T6). 
Table 2. Particle size distribution respect to the daily total concentration (PSD\%) values, for P1, P2 and $\mathrm{P} 3$ in the six time slots (T1-T6) for NM and AM distributions.

\begin{tabular}{ccccccc}
\hline & \multicolumn{3}{c}{ NM (\%) } & \multicolumn{3}{c}{ AM (\%) } \\
\cline { 2 - 7 } & P1 & P2 & P3 & P1 & P2 & P3 \\
\hline T1 & 24.4 & 5.8 & 7.8 & 75.6 & 94.2 & 92.2 \\
T2 & 29.6 & 10.9 & 11.5 & 70.4 & 89.1 & 88.5 \\
T3 & 37.6 & 19.9 & 25.3 & 62.4 & 80.1 & 74.7 \\
T4 & 35.8 & 32.5 & 28.4 & 64.2 & 67.5 & 71.6 \\
T5 & 36.7 & 23.2 & 34.0 & 63.3 & 76.8 & 66.0 \\
T6 & 19.8 & 11.9 & 16.1 & 80.2 & 88.1 & 83.9 \\
\hline Mean & 30.7 & 17.4 & 20.5 & 69.4 & 82.6 & 79.5 \\
\hline
\end{tabular}

The observed ratio between $\mathrm{AM}$ and NM (AM/NM) is 2.5 in the weekend (P1) and 6.2 in the working days (P2 and P3). Furthermore, high variability of PSD values are observed during the $24 \mathrm{~h}$ : AM/NM ratio in the working days nighttime (T1, T2 and T6) is 9.4 and in the working days daytime (T3, T4 and T5) is 2.8; similarly, in the weekend AM/NM ratio is 3.2 and 1.7 respectively for nighttime and daytime.

All the ratios indicate a strong differentiation between working and non-working days. The contribution of the AM is always higher than the NM, regardless of the time slots and the day of the week. In particular, the ratio AM/NM in the working days is about 3.0 and 1.6 times greater than the weekend, in the nighttime and in daytime respectively.

Figure 5 shows these results for each time slots (T1-T6) and in P1, P2, P3. The high concentrations reported on working days are probably due to anthropogenic activities and they might favor the coagulation and aggregation phenomena of airborne particles in the AM that reaches its maximum value during the night.

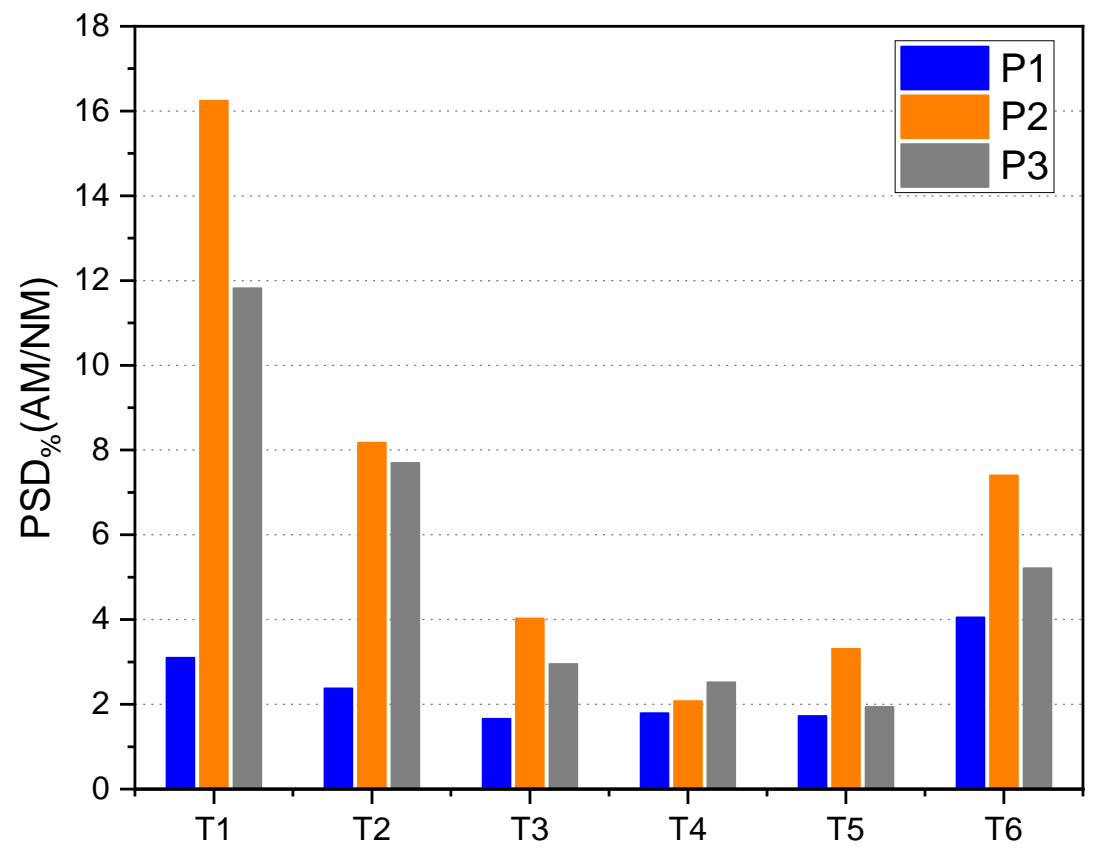

Figure 5. Particle size distribution respect to the daily total concentration (PSD\%) average ratio between AM and NM, during P1, P2 and P3 for the six time slots (T1-T6).

To sum up these findings confirm and support the previous TPNC and $D_{\text {avg }}$ time series results (Figure 2), showing that in the working days the great amount of particles in the nighttime refers to AM.

$\mathrm{NM}$ and AM distributions are characterized by different and well distinguished average diameters (Table 3). In fact, the average peak diameter for NM in P1, P2 and P3 is 
$10.5 \pm 0.1 \mathrm{~nm}$ and for $\mathrm{AM}$ is $81.4 \pm 8.3 \mathrm{~nm}$. The corresponding CV is 0.008 for $\mathrm{NM}$ and 0.102 for AM, thus indicating the greater variability of AM peak position than the NM. These data are consistent with the literature as NM can be mainly associated to fresh/primary particles (i.e., diesel exhaust particles from outdoor, heating or natural sources) while AM includes not only primary particles but also those that have aggregated or coming from different particulate sources (either indoor or outdoor) [32].

Table 3. Modal peak position of nucleation mode (NM) and accumulation mode (AM) distributions for P1, P2 and P3 in the six time slots (T1-T6).

\begin{tabular}{ccccccc}
\hline & & NM & & & AM & \\
\cline { 2 - 7 } & P1 & P2 & P3 & P1 & P2 & P3 \\
\hline T1 & 10.5 & 10.4 & 10.4 & 73.0 & 87.7 & 89.2 \\
T2 & 10.5 & 10.5 & 10.4 & 76.0 & 92.4 & 93.0 \\
T3 & 10.5 & 10.6 & 10.6 & 68.0 & 89.9 & 88.7 \\
T4 & 10.5 & 10.4 & 10.3 & 69.0 & 82.6 & 82.0 \\
T5 & 10.5 & 10.4 & 10.3 & 67.0 & 81.8 & 80.1 \\
T6 & 10.5 & 10.4 & 10.4 & 76.0 & 83.0 & 85.0 \\
\hline Mean & 10.5 & 10.5 & 10.4 & 71.5 & 86.2 & 86.3 \\
\hline
\end{tabular}

\section{3. $p P A H s$ in the NM and $A M$}

PCA results are shown in Figure 6. The first and the second principal components explain $71.53 \%$ and $26.31 \%$ of the total variance. PCA was carried out on data that were firstly unit variance scaled and mean centered. In the loading plot (Figure 6a) TPNC, pPAHs and AM are grouped together contributing to the same information (positively correlated) and their direction is coincident with the first principal component whereas $\mathrm{NM}$ is independent by other variables (direction orthogonal with respect to PNC, pPAHs and $\mathrm{AM}$ ) and its direction is coincident with the second principal component. In the score plot (Figure 6b) the data points referred to the weekend (empty circles), for every time slot, are grouped together in the opposite side of the first component (i.e., pPAHs concentration) whereas data points referred to the working days (full circles) mainly correlate with pPAHs concentration during the nighttime (blue tones) and with pPAHs and NM during the day time (red tones).

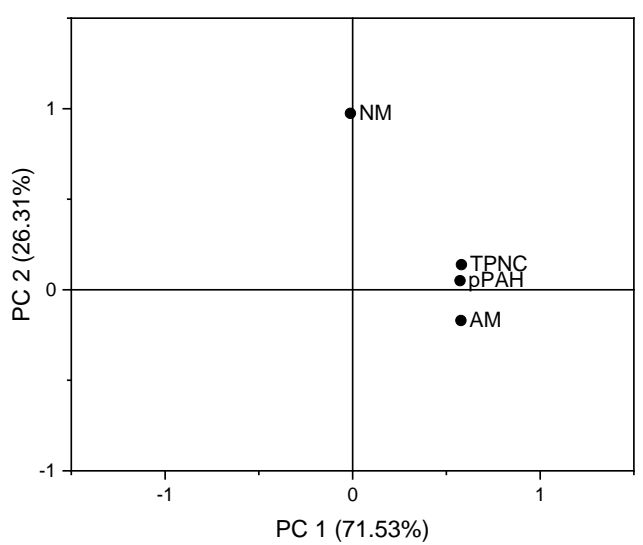

(a)

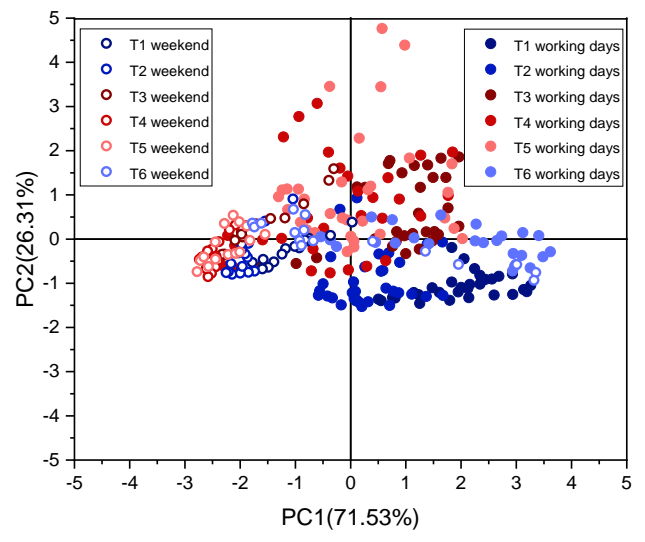

(b)

Figure 6. Principal Component Analysis (PCA) loadings plot (a) and scores plot (b) obtained for particle-bound polycyclic aromatic hydrocarbons (pPAHs), total particle number concentration (TPNC), nucleation mode (NM) and accumulation mode (AM) according to night-time slots (blue tones: T1, T2 and T6) and day-time slots (red tones: T3, T4 and T5) in non-working (empty circles) and working days (full circles). 
Starting from the qualitative considerations allowed by the PCA, we proceed with the estimation of parameters that describe the correlations between the variables. Figure 7 shows TPNC and pPAHs time series, day by day; the correlation between pPAHs, TPNC, $\mathrm{NM}$ and AM distributions in the weekend and in the working days are shown respectively in (Figure 8a,b).

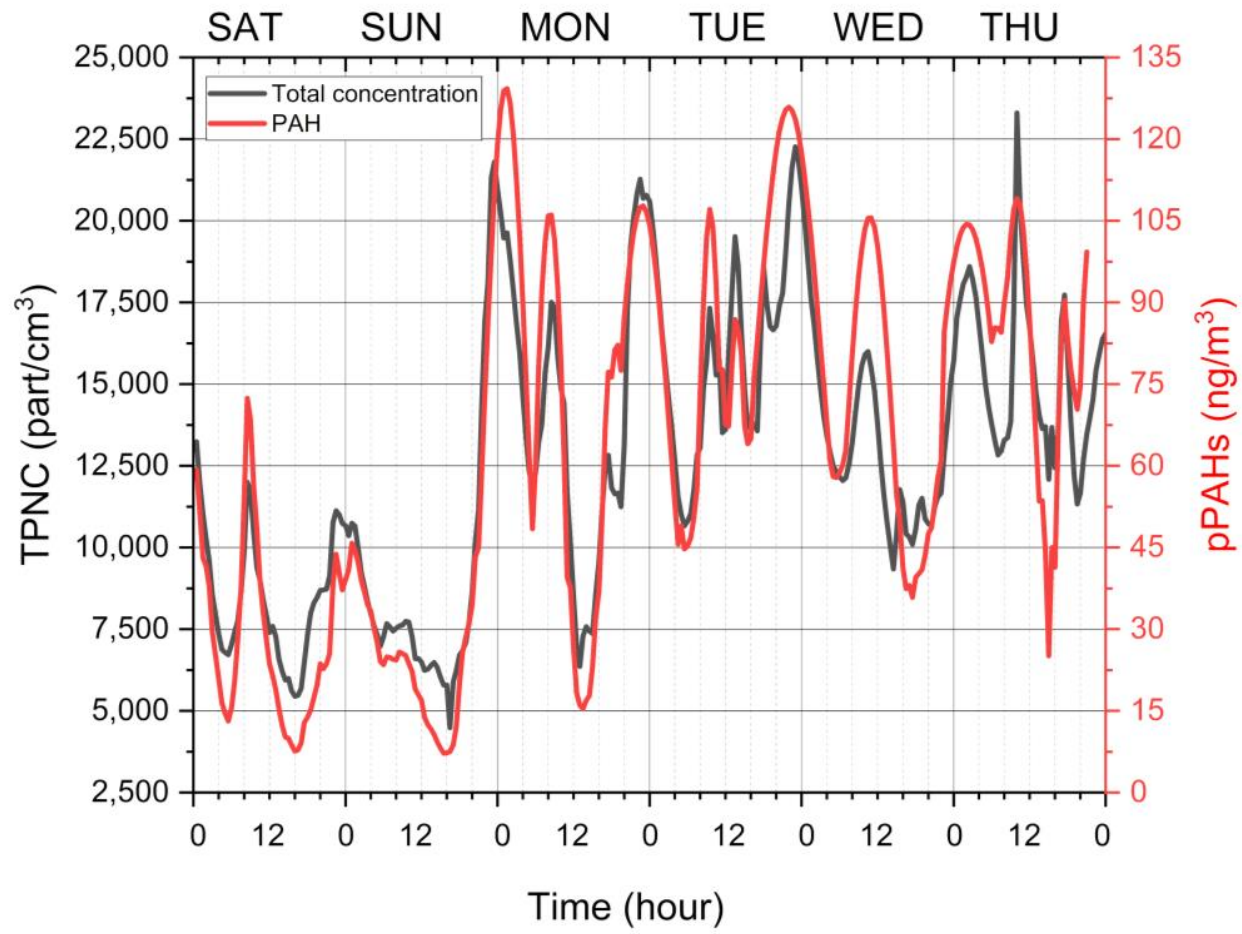

Figure 7. Indoor time series of total particle number concentration (TPNC, black curve) and particlebound polycyclic aromatic hydrocarbons (pPAHs, red curve).

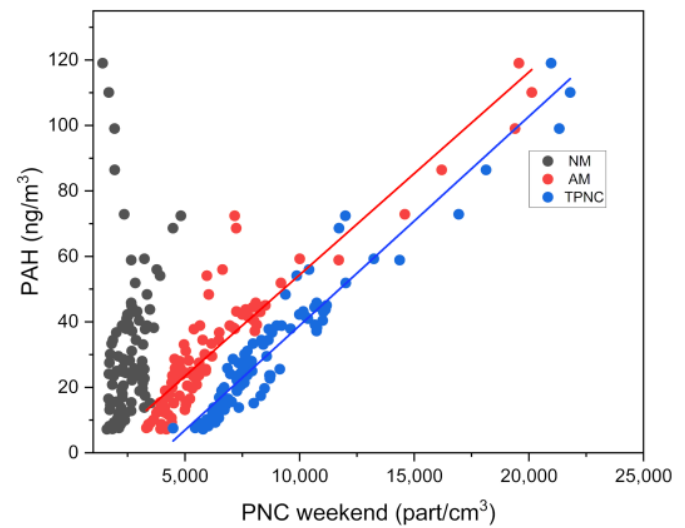

(a)

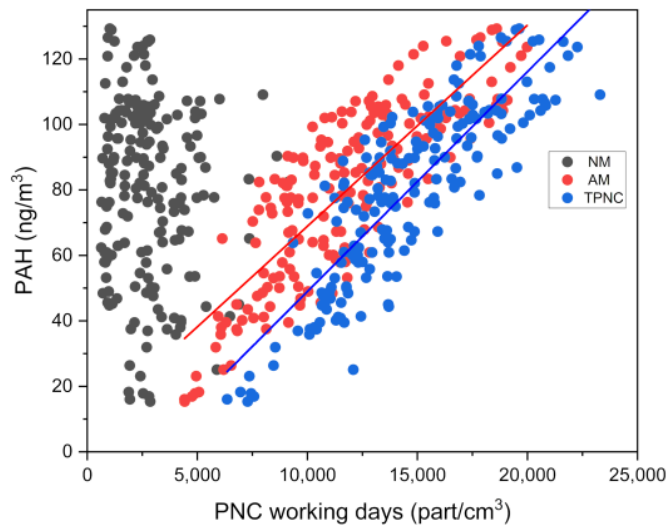

(b)

Figure 8. Particle-bound polycyclic aromatic hydrocarbons (pPAHs) concentration versus nucleation mode (NM), accumulation mode (AM) and total particle number concentration (TPNC) in the non-working days (a) and in the working days (b).

Correlation parameters are reported in Table 4 . The linear correlations between pPAHs, TPNC and AM in the working days (pPAHs: mean $=79.98 \mathrm{ng} / \mathrm{m}^{3} ;$ Std. Dev. $=26.96 \mathrm{ng} / \mathrm{m}^{3}$; $\mathrm{CV}=0.34$ ) and in the weekend (pPAHs: mean $=30.77 \mathrm{ng} / \mathrm{m}^{3} ;$ Std. Dev. $=21.67 \mathrm{ng} / \mathrm{m}^{3}$; $\mathrm{CV}=0.70$ ) show about the same slope and pPAHs concentrations are in accordance with those reported by Srogi [71]. 
Table 4. Correlation parameters (slope, intercept and $\mathrm{R}^{2}$ ) between particle-bound polycyclic aromatic hydrocarbons (pPAHs) and nucleation mode (NM), accumulation mode (AM), total particle number concentration (TPNC) respectively, in non-working and working days.

\begin{tabular}{ccccccc}
\hline & \multicolumn{3}{c}{ Non-Working Days } & \multicolumn{3}{c}{ Working Days } \\
\cline { 2 - 6 } & Slope $^{*}$ & Intercept $^{* *}$ & $\mathbf{R}^{\mathbf{2}}$ & Slope $^{*}$ & Intercept $^{* *}$ & $\mathbf{R}^{\mathbf{2}}$ \\
\hline NM & 0.006 & 14.4 & 0.040 & -0.001 & 83.5 & 0.006 \\
AM & 0.006 & -7.5 & 0.900 & 0.006 & 7.4 & 0.700 \\
TPNC & 0.006 & -25.0 & 0.900 & 0.006 & -18.2 & 0.700 \\
\hline
\end{tabular}

* $\left(\mathrm{ng} / \mathrm{m}^{3}\right) /\left(\right.$ part $\left./ \mathrm{cm}^{3}\right) ; * *\left(\mathrm{ng} / \mathrm{m}^{3}\right)$.

These figures show that inside the CR particles bounded with PAHs are about $0.6 \%$ of TPNC. A non-linear correlation occurs between PAHs and NM. It is worth noting that PAHs can be likely bounded on particles having size diameter greater than $30 \mathrm{~nm}$ (AM).

\section{Conclusions}

In the present study we analyzed ultrafine PSD and their relationship with TPNC and $D_{a v g}$, as a contribution to characterize by size the indoor exposure to UFPs in a computer classroom at the site of University of Rome "Sapienza" (Italy). High frequency $(1 \mathrm{~Hz})$ data were collected in a weekly campaign including working and non-working days, for six different daily time slots, covering both night and daily time periods. UFPs contribution to NM and AM have been highlighted, including statistical analysis of pPAHs and TPNC correlations with aforementioned two size modes.

High TPNC values registered inside the CR during the rush hours (early morning and $\mathrm{mid} /$ late afternoon) are according to the outdoor influences originated from anthropogenic activities. This is confirmed by similar daily trends of TPNC observed in working and non-working days, even if the values in Saturday and Sunday were lower than in the working days.

It is noting that PSD analysis reveals a site-specific condition in which the AM contributions are always greater than the NM ones inside the $\mathrm{CR}$, not already reported for other different work environments [69,72].

NM can be mainly associated to fresh/primary traffic exhaust particles, heating or natural sources from outdoor while AM includes both primary and aged particles coming from different indoor or outdoor sources [32,70].

During the weekend the NM distribution is about the same and not dependent by the time slot, while higher variability occurred during the working days in which the great amount of particles refers to $\mathrm{AM}$, in particular during the nighttime.

AM mainly contribute to the TPNC inside the CR during working days showing high correlation with indoor pPAHs, probably associated to the accumulation of outdoor contributions seeing as inside the CR primary pPAHs sources are not usually present. These findings may have an impact in terms of occupational health since there are many evidences that indoor exposures to PAHs may be associated with adverse health effects also in working environments [73].

The analysis conducted on the high-frequency data of working/non-working days highlights the complexity of indoor dynamics, not only related to the presence/absence of internal work-related sources, but also influenced by the background characteristic of indoor environments and further investigation are needed in this view.

Finally, recent studies highlighted the important role of indoor air quality in SARSCoV-2 transmission, highlighting that virus particles may have similar dynamics than other suspended UFPs (e.g., arising from road traffic, heating or other sources) [74-76]. In this context, although there is a need for more specific research exploring possible interactions between air pollutants in the ambient air and SARS-CoV-2 impact on human health, the proposed methodological approach may provide useful indications, with specific reference 
to the relevance of relative ratios of different UFPs size distribution modes and the diffusion of Sars-CoV-2 in indoor environments.

Author Contributions: Conceptualization, F.B., R.F., F.T., S.I. and A.P.; Data curation, F.B., R.F. and F.T.; Formal analysis, F.B., R.F., F.T. and A.P.; Funding acquisition, S.I. and A.P.; Investigation, F.B., R.F. and F.T.; Methodology, F.B., R.F. and F.T.; Project administration, A.P.; Resources, S.I. and A.P.; Software, F.B., R.F. and F.T.; Supervision, S.I. and A.P.; Validation, S.I. and A.P.; Visualization, F.B., R.F. and F.T.; Writing-original draft, F.B., R.F., F.T. and A.P.; Writing-review \& editing, F.B., R.F., F.T., S.I. and A.P. All authors have read and agreed to the published version of the manuscript.

Funding: This research was funded by Italian Workers Compensation Authority (INAIL) in the frame of its scientific research programs (2016-2018).

Conflicts of Interest: The authors declare no conflict of interest.

\section{References}

1. Lelieveld, J.; Evans, J.S.; Fnais, M.; Giannadaki, D.; Pozzer, A. The contribution of outdoor air pollution sources to premature mortality on a global scale. Nat. Cell Biol. 2015, 525, 367-371. [CrossRef]

2. Nazaroff, W.W. The particles around us. Indoor Air 2018, 28, 215-217. [CrossRef]

3. Oberdörster, G. Pulmonary effects of inhaled ultrafine particles. Int. Arch. Occup. Environ. Health 2000, 74, 1-8. [CrossRef] [PubMed]

4. Pelliccioni, A.; Gherardi, M. Development and validation of an intra-calibration procedure for MiniDISCs measuring ultrafine particles in multi-spatial indoor environments. Atmos. Environ. 2021, 246, 118154. [CrossRef]

5. Oberdörster, G.; Oberdörster, E.; Oberdörster, J. Nanotoxicology: An Emerging Discipline Evolving from Studies of Ultrafine Particles. Environ. Health Perspect. 2005, 113, 823-839. [CrossRef] [PubMed]

6. Kozawa, K.H.; Winer, A.M.; Fruin, S.A. Ultrafine particle size distributions near freeways: Effects of differing wind directions on exposure. Atmos. Environ. 2012, 63, 250-260. [CrossRef]

7. Kumar, P.; Morawska, L.; Birmili, W.; Paasonen, P.; Hu, M.; Kulmala, M.; Harrison, R.M.; Norford, L.; Britter, R. Ultrafine particles in cities. Environ. Int. 2014, 66, 1-10. [CrossRef] [PubMed]

8. Viitanen, A.-K.; Uuksulainen, S.; Koivisto, A.J.; Hämeri, K.; Kauppinen, T. Workplace Measurements of Ultrafine Particles-A Literature Review. Ann. Work Expo. Health 2017, 61, 749-758. [CrossRef]

9. Ohlwein, S.; Kappeler, R.; Joss, M.K.; Künzli, N.; Hoffmann, B. Health effects of ultrafine particles: A systematic literature review update of epidemiological evidence. Int. J. Public Health 2019, 64, 547-559. [CrossRef] [PubMed]

10. Marcias, G.; Fostinelli, J.; Sanna, A.M.; Uras, M.; Catalani, S.; Pili, S.; Fabbri, D.; Pilia, I.; Meloni, F.; Lecca, L.I.; et al. Occupational Exposure to Fine Particles and Ultrafine Particles in a Steelmaking Foundry. Metals 2019, 9, 163. [CrossRef]

11. Samoli, E.; Rodopoulou, S.; Schneider, A.; Morawska, L.; Stafoggia, M.; Renzi, M.; Breitner, S.; Lanki, T.; Pickford, R.; Schikowski, T.; et al. Meta-analysis on short-term exposure to ambient ultrafine particles and respiratory morbidity. Eur. Respir. Rev. 2020, 29, 200116. [CrossRef] [PubMed]

12. Lehtomäki, H.; Korhonen, A.; Asikainen, A.; Karvosenoja, N.; Kupiainen, K.; Paunu, V.-V.; Savolahti, M.; Sofiev, M.; Palamarchuk, Y.; Karppinen, A.; et al. Health Impacts of Ambient Air Pollution in Finland. Int. J. Environ. Res. Public Health 2018, 15, 736. [CrossRef] [PubMed]

13. Donaldson, K.; Stone, V.; Clouter, A.; Renwick, L.; MacNee, W. Ultrafine particles. Occup. Environ. Med. 2001, 58, 211-216. [CrossRef] [PubMed]

14. Miller, M.R.; Raftis, J.B.; Langrish, J.P.; McLean, S.G.; Samutrtai, P.; Connell, S.P.; Wilson, S.; Vesey, A.T.; Fokkens, P.H.B.; Boere, A.J.F.; et al. Inhaled Nanoparticles Accumulate at Sites of Vascular Disease. ACS Nano 2017, 11, 4542-4552. [CrossRef] [PubMed]

15. Kwon, H.-S.; Ryu, M.H.; Carlsten, C. Ultrafine particles: Unique physicochemical properties relevant to health and disease. Exp. Mol. Med. 2020, 52, 318-328. [CrossRef]

16. Costabile, F.; Gualtieri, M.; Ancona, C.; Canepari, S.; Decesari, S. Ultrafine Particle Features Associated with Pro-Inflammatory and Oxidative Responses: Implications for Health Studies. Atmosphere 2020, 11, 414. [CrossRef]

17. Chen, C.; Yao, M.; Luo, X.; Zhu, Y.; Liu, Z.; Zhuo, H.; Zhao, B. Outdoor-to-Indoor Transport of Ultrafine Particles: Measurement and Model Development of Infiltration Factor. Environ. Pollut. 2020, 267, 115402. [CrossRef]

18. Whitby, K.T. The physical characteristics of sulfur aerosols. Sulfur Atmos. 1978, 12, 135-159. [CrossRef]

19. McMurry, P.H.; Shepherd, M.F.; Vickery, J.S. Particulate Matter Science for Policy Makers: A NARSTO Assessment; NARSTO: Pasco, WA, USA, 2005.

20. Nøjgaard, J.K.; Nguyen, Q.T.; Glasius, M.; Sørensen, L.L. Nucleation and Aitken mode atmospheric particles in relation to $\mathrm{O}_{3}$ and NOX at semirural background in Denmark. Atmos. Environ. 2012, 49, 275-283. [CrossRef]

21. Baldauf, R.W.; Devlin, R.B.; Gehr, P.; Giannelli, R.; Hassett-Sipple, B.; Jung, H.; Martini, G.; McDonald, J.; Sacks, J.D.; Walker, K. Ultrafine Particle Metrics and Research Considerations: Review of the 2015 UFP Workshop. Int. J. Environ. Res. Public Health 2016, 13, 1054. [CrossRef] 
22. Gong, J.; Zhu, T.; Hu, M.; Wu, Z.; Zhang, J.J. Different metrics (number, surface area, and volume concentration) of urban particles with varying sizes in relation to fractional exhaled nitric oxide (FeNO). J. Thorac. Dis. 2019, 11, 1714-1726. [CrossRef]

23. Burkart, J.; Willis, M.D.; Bozem, H.; Thomas, J.L.; Law, K.S.; Hoor, P.; Aliabadi, A.A.; Köllner, F.; Schneider, J.; Herber, A.; et al. Summertime observations of elevated levels of ultrafine particles in the high Arctic marine boundary layer. Atmos. Chem. Phys. Discuss. 2017, 17, 5515-5535. [CrossRef]

24. Moreno-Ríos, A.L.; Tejeda-Benítez, L.P.; Bustillo-Lecompte, C.F. Sources, characteristics, toxicity, and control of ultrafine particles: An overview. Geosci. Front. 2021. [CrossRef]

25. Heinzerling, A.; Hsu, J.; Yip, F. Respiratory Health Effects of Ultrafine Particles in Children: A Literature Review. Water Air Soil Pollut. 2016, 227, 32. [CrossRef]

26. Boccuni, F.; Rondinone, B.; Petyx, C.; Iavicoli, S. Potential occupational exposure to manufactured nanoparticles in Italy. J. Clean. Prod. 2008, 16, 949-956. [CrossRef]

27. Stone, V.; Miller, M.R.; Clift, M.J.; Elder, A.; Mills, N.L.; Møller, P.; Schins, R.P.; Vogel, U.; Kreyling, W.G.; Jensen, K.A.; et al. Nanomaterials Versus Ambient Ultrafine Particles: An Opportunity to Exchange Toxicology Knowledge. Environ. Health Perspect. 2017, 125, 106002. [CrossRef]

28. Sarwar, F.; Malik, R.N.; Chow, C.W.; Alam, K. Occupational exposure and consequent health impairments due to potential incidental nanoparticles in leather tanneries: An evidential appraisal of south Asian developing countries. Environ. Int. 2018, 117, 164-174. [CrossRef]

29. Argyropoulos, G.; Samara, C.; Voutsa, D.; Kouras, A.; Manoli, E.; Voliotis, A.; Tsakis, A.; Chasapidis, L.; Konstandopoulos, A.; Eleftheriadis, K. Concentration levels and source apportionment of ultrafine particles in road microenvironments. Atmos. Environ. 2016, 129, 68-78. [CrossRef]

30. Feng, Y.; Li, Y.; Cui, L. Critical review of condensable particulate matter. Fuel 2018, 224, 801-813. [CrossRef]

31. Di Gilio, A.; Palmisani, J.; Trizio, L.; Saracino, G.; Giua, R.; De Gennaro, G. Total p-PAH Levels Nearby a Complex Industrial Area: A Tailored Monitoring Experiment to Assess the Impact of Emission Sources. Atmosphere 2020, 11, 469. [CrossRef]

32. Bukowiecki, N.; Kittelson, D.B.; Watts, W.F.; Burtscher, H.; Weingartner, E.; Baltensperger, U. Real-time characterization of ultrafne and accumulation mode particles in ambient combustion aerosols. J. Aerosol. Sci. 2002, 33, 1139-1154. [CrossRef]

33. Junkermann, W.; Hacker, J.M. Ultrafine Particles in The Lower Tropospehe. Major Sources, Invisible Plumes, and Meteoro-logical Transport Processes. Bull. Am. Meteorol. Soc. 2018, 99, 2587-2602. [CrossRef]

34. Junkermann, W.; Vogel, B.; Sutton, M.A. The climate penalty for clean fossil fuel combustion. Atmos. Chem. Phys. Discuss. 2011, 11, 12917-12924. [CrossRef]

35. Junkermann, W.; Hacker, J.M. Ultrafine particles over Eastern Australia: An airborne survey. Tellus B Chem. Phys. Meteorol. 2015, 67, 67. [CrossRef]

36. Bigg, E.; Ayers, G.; Turvey, D. Measurement of the dispersion of a smoke plume at large distances from the source. Atmos. Environ. 1978, 12, 1815-1818. [CrossRef]

37. Junkermann, W.; Hacker, J.; Lyons, T.; Nair, U. Land use change suppresses precipitation. Atmos. Chem. Phys. Discuss. 2009, 9, 6531-6539. [CrossRef]

38. Urbanski, S.P.; Hao, W.M.; Baker, S. Chapter 4 Chemical Composition of Wildland Fire Emissions. In Wildland Fires and Air Pollution; Bytnerowicz, A., Arbo, M., Riebau, A., Andersen, C., Eds.; Elsevier: Amsterdam, The Netherlands, 2008 ; pp. 79-107.

39. Hosseini, S.; Li, Q.; Cocker, D.; Weise, D.; Miller, A.; Shrivastava, M.; Miller, J.W.; Mahalingam, S.; Princevac, M.; Jung, H. Particle size distributions from laboratory-scale biomass fires using fast response instruments. Atmos. Chem. Phys. 2010, 10, 8065-8076. [CrossRef]

40. Rivas, I.; Viana, M.; Moreno, T.; Bouso, L.; Pandolfi, M.; Alvarez-Pedrerol, M.; Forns, J.; Alastuey, A.; Sunyer, J.; Querol, X. Outdoor infiltration and indoor contribution of UFP and BC, OC, secondary inorganic ions and metals in PM2.5 in schools. Atmos. Environ. 2015, 106, 129-138. [CrossRef]

41. Pelliccioni, A.; Monti, P.; Cattani, G.; Boccuni, F.; Cacciani, M.; Canepari, S.; Capone, P.; Catrambone, M.; Cusano, M.; D’Ovidio, M.C.; et al. Integrated Evaluation of Indoor Particulate Exposure: The VIEPI Project. Sustainability 2020, 12, 9758. [CrossRef]

42. Wallace, L.; Ott, W. Personal exposure to ultrafine particles. J. Expo. Sci. Environ. Epidemiol. 2011, 21, 20-30. [CrossRef]

43. Bhangar, S.; Mullen, N.A.; Hering, S.V.; Kreisberg, N.M.; Nazaroff, W.W. Ultrafine particle concentrations and exposures in seven residences in northern California. Indoor Air 2010, 21, 132-144. [CrossRef] [PubMed]

44. Beko, G.; Weschler, C.J.; Wierzbicka, A.; Karottki, D.G.; Toftum, J.; Loft, S.; Clausen, G. Ultrafine particles: Exposure and source apportionment in 56 Danish homes. Environ. Sci. Technol. 2013, 47, 10240-10248. [PubMed]

45. Afshari, A.; Matson, U.; Ekberg, L.E. Characterization of indoor sources of fine and ultrafine particles: A study conducted in a full-scale chamber. Indoor Air 2005, 15, 141-150. [CrossRef]

46. D'Amico, A.; Pini, A.; Zazzini, S.; D’Alessandro, D.; Leuzzi, G.; Currà, E. Modelling VOC Emissions from Building Materials for Healthy Building Design. Sustainability 2020, 13, 184. [CrossRef]

47. Licina, D.; Nazaroff, W.W. Clothing as a transport vector for airborne particles: Chamber study. Indoor Air 2018, 28, 404-414. [CrossRef]

48. Buonanno, G.; Fuoco, F.; Marini, S.; Stabile, L. Particle Resuspension in School Gyms during Physical Activities. Aerosol Air Qual. Res. 2012, 12, 803-813. [CrossRef] 
49. Marcovecchio, F.; Perrino, C. Bioaerosol Contribution to Atmospheric Particulate Matter in Indoor University Environments. Sustainability 2021, 13, 1149. [CrossRef]

50. Singer, B.C.; Destaillats, H.; Hodgson, A.T.; Nazaroff, W.W. Cleaning products and air fresheners: Emissions and resulting concentrations of glycol ethers and terpenoids. Indoor Air 2006, 16, 179-191. [CrossRef] [PubMed]

51. Trantallidi, M.; Dimitroulopoulou, C.; Wolkoff, P.; Kephalopoulos, S.; Carrer, P. EPHECT III: Health risk assessment of ex-posure to household consumer products. Sci. Total Environ. 2015, 536, 903-913. [CrossRef]

52. Waring, M.S. Secondary organic aerosol in residences: Predicting its fraction of fine particle mass and determinants of for-mation strength. Indoor Air 2014, 24, 376-389. [CrossRef]

53. Kruza, M.; McFiggans, G.; Waring, M.; Wells, J.; Carslaw, N. Indoor secondary organic aerosols: Towards an improved representation of their formation and composition in models. Atmos. Environ. 2020, 240, 117784. [CrossRef] [PubMed]

54. Castellano, P.; Canepari, S.; Ferrante, R.; L'Episcopo, N. Multiparametric approach for an exemplary study of laser printer emissions. J. Environ. Monit. 2012, 14, 446-454. [CrossRef] [PubMed]

55. Wensing, M.; Schripp, T.; Uhde, E.; Salthammer, T. Ultra-fine particles release from hardcopy devices: Sources, real-room measurements and efficiency of filter accessories. Sci. Total. Environ. 2008, 407, 418-427. [CrossRef] [PubMed]

56. Baron, P.A.; Willeke, K. Aerosol Measurement Principles, Techniques and Applications, 2nd ed.; Wiley-Interscience: Washington, DC, USA, 2001.

57. Morawska, L.; Afshari, A.; Bae, G.N.; Buonanno, G.; Chao, C.Y.H.; Hänninen, O.; Hofmann, W.; Isaxon, C.; Jayaratne, E.R.; Pasanen, P.; et al. Indoor aerosols: From personal exposure to risk assessment. Indoor Air 2013, 23, 462-487. [CrossRef] [PubMed]

58. Pini, A.; Musa, I.; Monti, P.; Leuzzi, G.; Di Bernardino, A.; Cattani, G.; Bcchianico, A.D.M.D.; Gherardi, M.; Pelliccioni, A. Numerical and experimental analysis of flow and particulate matter dispersion in indoor environment. IOP Conf. Ser. Earth Environ. Sci. 2020, 489, 489. [CrossRef]

59. Ferrante, R.; Boccuni, F.; Tombolini, F.; Iavicoli, S. Measurement techniques of exposure to nanomaterials in workplaces. In Nanotechnology in Eco-Efficient Construction; Elsevier: Amsterdam, The Netherlands, 2019; pp. 785-813.

60. Asbach, C.; Kaminski, H.; Fissan, H.; Monz, C.; Dahmann, D.; Mülhopt, S.; Paur, H.R.; Kiesling, H.J.; Herrmann, F.; Voetz, M.; et al. Comparison of four mobility particle sizers with different time resolution for stationary exposure measurements. J. Nanopart. Res. 2009, 11, 1593-1609. [CrossRef]

61. Cowen, K.; Kelly, T.; Coutant, B.; Riggs, K. Environmental Technology Verification Report; Ecochem Analytics PAS 2000 Particulate PAH Monitor; Battelle; U.S. Environmental Protection Agency: Washington, DC, USA, 2001.

62. TSI. Aerosol Statistics Lognormal Distributions And dN/dlogDp; Application Note PR-001; TSI: Sunnyvale, CA, USA, 2012.

63. Eriksson, L.; Byrne, T.; Johansson, E.; Trygg, J.; Wikstrom, C. PCA. In Multi and Megavariate Data Analysis Basic Principles and Application, 3rd ed.; UMETRICS: Malmo, Sweden, 2013; pp. 33-54.

64. Boccuni, F.; Ferrante, R.; Tombolini, F.; Iavicoli, S.; Pelliccioni, A. Measurement of airborne ultrafine particles in work and life environments: Study design and preliminary trends in an Italian university site. IOP Conf. Ser. Mater. Sci. Eng. 2019, 609, 042077. [CrossRef]

65. Settimo, G.; Soggiu, M.; Inglessis, M.; Manigrasso, M.; Avino, P. Submicron and Ultrafine Particles in Downtown Rome: How the Different Euro Engines Have Influenced Their Behavior for Two Decades. Atmosphere 2020, 11, 894. [CrossRef]

66. McMurry, P.H.; Woo, K.S. Size Distributions of 3-100-nm Urban Atlanta Aerosols: Measurement and Observations. J. Aerosol Med. 2002, 15, 169-178. [CrossRef]

67. Gariazzo, C.; Pelliccioni, A. A Multi-City Urban Population Mobility Study Using Mobile Phone Traffic Data. Appl. Spat. Anal. Policy 2019, 12, 753-771. [CrossRef]

68. Von Barany, D.; Kuhlbusch, T.A.; Monz, C.; Dziurowitz, N.; Pelzer, J.; Vossen, K.; Dietrich, S.; Götz, U.; Kiesling, H.-J.; Asbach, C.; et al. Comparability of Portable Nanoparticle Exposure Monitors. Ann. Occup. Hyg. 2012, 56, 606-621. [CrossRef]

69. Boccuni, F.; Ferrante, R.; Tombolini, F.; Natale, C.; Gordiani, A.; Sabella, S.; Iavicoli, S. Occupational exposure to graphene and silica nanoparticles. Part I: Workplace measurements and samplings. Nanotoxicology 2020, 14, 1280-1300. [CrossRef]

70. Rivas, I.; Beddows, D.C.; Amato, F.; Green, D.C.; Järvi, L.; Hueglin, C.; Reche, C.; Timonen, H.; Fuller, G.W.; Niemi, J.V.; et al. Source apportionment of particle number size distribution in urban background and traffic stations in four European cities. Environ. Int. 2020, 135, 105345. [CrossRef] [PubMed]

71. Srogi, K. Monitoring of environmental exposure to polycyclic aromatic hydrocarbons: A review. Environ. Chem. Lett. 2007, 5, 169-195. [CrossRef] [PubMed]

72. Zou, H.; Zhang, Q.; Xing, M.; Gao, X.; Zhou, L.; Tollerud, D.J.; Tang, S.; Zhang, M. Relationships between number, surface area, and mass concentrations of different nanoparticles in workplaces. Environ. Sci. Process. Impacts 2015, 17, 1470-1481. [CrossRef] [PubMed]

73. Prüss-Ustün, A.; Wolf, J.; Corvalán, C.; Bos, R.; Neira, M. Preventing Disease through Healthy Environments-A Global Assessment of the Burden of Disease from Environmental Risks; World Health Organization: Geneva, Switzerland, 2016.

74. Bourdrel, T.; Annesi-Maesano, I.; Alahmad, B.; Maesano, C.N.; Bind, M.-A. The impact of outdoor air pollution on COVID-19: A review of evidence from in vitro, animal, and human studies. Eur. Respir. Rev. 2021, 30, 200242. [CrossRef] [PubMed] 
75. D'Alessandro, D.; Gola, M.; Appolloni, L.; Dettori, M.; Fara, G.M.; Rebecchi, A.; Settimo, G.; Capolongo, S. COVID-19 and Living space challenge. Well-being and Public Health recommendations for a healthy, safe, and sustainable housing. Acta BioMedica 2020, 91, 61-75. [PubMed]

76. Brunekreef, B.; Downward, G.; Forastiere, F.; Gehring, U.; Heederik, D.J.J.; Hoek, G.; Koopmans, M.P.G.; Smit, L.A.M.; Vermeulen, R.C.H. Air pollution and COVID-19. In Including Elements of Air Pollution in Rural Areas, Indoor Air Pollution and Vulnerability and Resilience Aspects of Our Society Against Respiratory Disease, Social Inequality Stemming from Air Pollution; Study for the Committee on Environment, Public Health and Food Safety, Policy Department for Economic, Scientific and Quality of Life Policies; European Parliament: Luxembourg, 2021. 